
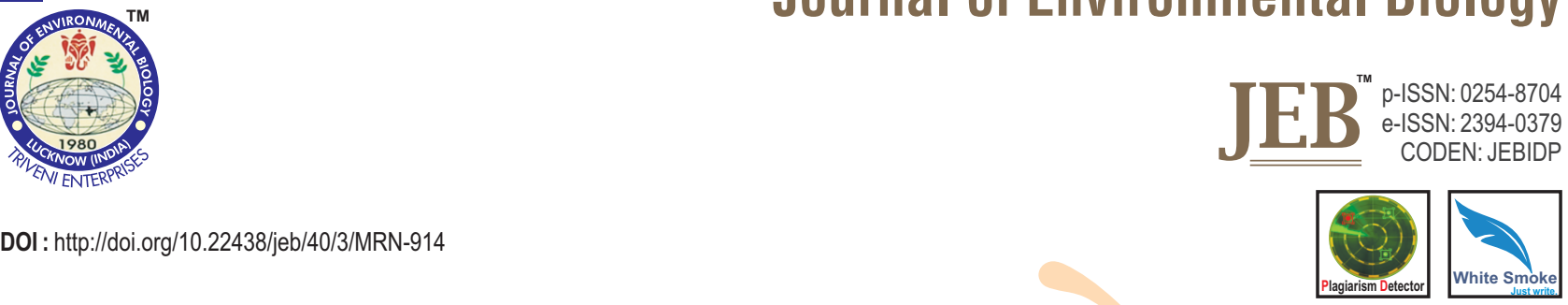

\title{
Isolation and characterization of sulphur oxidizing bacteria (Halothiobacillus sp.) from aquaculture farm soil
}

\begin{tabular}{llll}
\hline Paper received: 04.05.2018 & Revised received: 16.10 .2018 & Re-revised received: 11.12.2018 & Accepted: 07.01.2019 \\
\hline
\end{tabular}

\section{Authors Info \\ R.K. Nadella*, M. Vaiyapuri, \\ A.B. Kusunur, T.C. Joseph, \\ L.K. Velayudhan and \\ M.P. Mothadaka \\ MFB Division, ICAR-Central Institute of Fisheries Technology, Cochin-682 029, India \\ *Corresponding Author Email : e-mail: nranjeetkumar@gmail.com}

\section{Edited by \\ Dr. Abir Dey}

\section{Reviewed by}

Dr. Gyanaranjan Dash

Dr. G.M. Siddaiah

\section{Abstract}

Aim : Isolation and characterization of Halothiobacillus sp. from the shrimp aquaculture farm soil and their sulphur oxidation ability and utilization of $\mathrm{H}_{2} \mathrm{~S}$ in in-vitro model.

Methodology : Starkeys mineral salt medium was used to screen autotrophic sulphur oxidizing bacteria. For the qualitative screening, bacterial isolates were inoculated in mineral salt medium containing bromo phenol blue indicator to monitor change in $\mathrm{pH}$. The isolates were studied further for their sulphate ion production, sulphur oxidase enzyme production and utilization of $\mathrm{Na}_{2} \mathrm{~S}$. Identification was carried out by conventional biochemical and molecular methods.

Results : Fifty isolates showed distinct sulphur oxidizing ability on the mineral salt medium. The $\mathrm{pH}$ reduction test revealed that out of fifty isolates six could efficiently reduce the $\mathrm{pH}$ of the medium to 3.0 from an initial $\mathrm{pH}$ of 7 within $96 \mathrm{hr}$ of incubation at $30^{\circ} \mathrm{C}$. Maximum sulphate ion $\left(12.65 \mathrm{mg} \mathrm{ml}^{-1}\right)$ and sulphur oxidase enzyme (16.64 mM sulphate $\left.\mathrm{hr}^{-1} \mathrm{ml}^{-1}\right)$ was produced by a bacterial isolate, Halothiobacillus sp. strain rk3. All the six isolates efficiently utilized $\mathrm{Na}_{2} \mathrm{~S}$ in in-vitro conditions. Conventional and molecular identification (16S rRNA sequence analysis) revealed that the sulphur oxidizing bacterial isolates belonged to Halothiobacillus spp. Furthermore, sequencing similarity calculation showed an average nucleotide identity (ANI) values higher than $99 \%$ which suggests that the isolates were not genetically different.

\section{Isolation and characterization of sulphur oxidizing bacteria (Halothiobacillus sp.) from aquaculture farm soil}

Soil sample collected from aquaculture farms

\section{$\mathbb{1}$}

Enrichment and selective plating of sulphur oxidizing bacteria in MSM Medium

\section{$\Downarrow$}

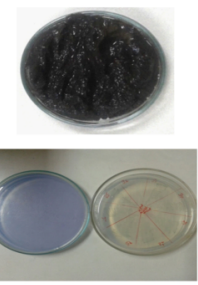

Screening of potential sulphur oxidizing bacteria by $\mathrm{pH}$ reduction, sulphate ion production \& sulphur oxidation assay

\section{$\llbracket$}

Identification of sulphur oxidizing bacteria by conventional biochemical and molecular methods

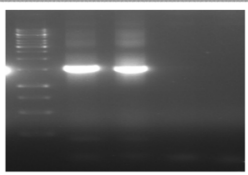

Interpretation : The present investigation revealed the presence of Halothiobacillus sp. as natural microflora of farm soils in shrimp aquaculture.

Key words: Aquaculture, Halothiobacillus, Sulphur oxidizing bacteria, Sulphur oxidase, Sulphate ion

How to cite : Nadella, R.K., M. Vaiyapuri, A.B. Kusunur, T.C. Joseph, L.K. Velayudhan and M.P. Mothadaka: Isolation and characterization of sulphur oxidizing bacteria (Halothiobacillus sp.) from aquaculture farm soil. J. Environ. Biol., 40, 363-369 (2019). 


\section{Introduction}

Bacteria are the major participants in the biogeochemical cycles of carbon, sulphur, nitrogen and phosphorous (Rojas et al., 2001) in natural environment. One such group of bacteria known as sulphate reducing bacteria uses sulphate ions as a terminal electron acceptor in their metabolism and produces sulphide which is toxic to the aquatic animals (Kawahara et al., 2008). On the other hand, another group of bacteria known as sulphur oxidizing bacteria metabolizes sulphide to sulphate which is nontoxic (Friedrich et al., 2001; Behra et al., 2014). The autotrophic sulphur oxidizing bacteria, viz., green sulphur bacteria and purple sulphur bacteria are facultative chemoautolithotrophs and are naturally found growing in environments with $\mathrm{pH}$ and temperature ranging between $1-9$ and $4^{\circ} \mathrm{C}-95^{\circ} \mathrm{C}$, respectively (Jorgensen and Revsbech 1983; Robertson et al., 2006). Among the autotrophic sulphur oxidizing bacteria, the genus Thiobacillus comprise of rod shaped Gram negative, colorless bacteria that has the ability to use sulphur compounds as electron donor for their growth (Kelly and Harrison, 1989). These organisms play a crucial role in the natural sulphur-cycle in both freshwater and saline environments (Kuenen et al., 1992).

In the present day, intensification of farming practices in shrimp aquaculture systems has led to the excessive use of highly proteinaceous feeds to increase production. This results in the deposition of unutilized feed in the pond bottom. The excess accumulation of unconsumed feed increases the biological oxygen demand in the aquatic system due to bacterial degradation that develops anaerobic condition. This favours the multiplication of sulphate reducing bacteria which utilizes sulphates for their metabolism and produce hydrogen sulphide (Boyd 1992; Abraham et al., 2004). Hydrogen sulphide is highly toxic at very low levels and penetrates across the cell membranes of the fish and other aquatic invertebrates resulting in acute mortalities (Colby and Smith, 1967). This can be ameliorated by supplementing sulphate oxidizing bacteria as bio-inoculants in the aquaculture farms.

Earlier, several attempts have been made to isolate and characterize sulphur oxidizing bacteria from the rhizosphere soi of paddy and groundnut, soil and water from coal mine, sewage and biogas slurry (Rangaswamy et al., 2005); cattle manure compost (Kumar et al., 2014); marine water, sewage and rhizosphere soil (Veerender et al., 2014) and different ecosystems (Sridar et al., 2015). Though there are few studies where investigation have been carried out to enumerate these bacteria from various aquaculture systems (Rao and Karunasagar 2000; Devaraja et al., 2002; Patil et al., 2012, 2015), there is a dearth of information on the isolation and characterization of obligate autotrophic sulphur oxidizing bacteria in aquaculture, except for the study of Abraham et al. (2015) who reported effective conversion of $\mathrm{H}_{2} \mathrm{~S}$ to sulphur compounds due to increase of sulphur oxidizing bacteria counts in shrimp farms. Although, the presence of sulphur oxidizing bacteria in the aquaculture farms have been reported, however, no study has been conducted on the in-vitro utilization of hydrogen-sulphide by these bacteria. Therefore, the present study was conducted to isolate and identify sulphur oxidizing bacteria from aquaculture farm soil and characterize their sulphur oxidation potential in in-vitro model.

\section{Materials and Methods}

Collection of soil sample: Soil samples (top soil about $1 \mathrm{~cm}$ ) were collected from mid-culture intensive shrimp farms located in Ernakulam District, Kerala, India. Soil samples collected in aseptic sample bags (Himedia, Mumbai, India) with proper labeling were brought to the laboratory in ice box and stored in a $\mathrm{BOD}$ incubator (Labline instruments, India) at $4 \pm 0.1^{\circ} \mathrm{C}$ for further analysis.

Sulphur oxidizing bacteria media: Mineral salt medium was used for the isolation of sulphur oxidizing bacteria (Starkey 1935); For plating, the plates were prepared with the addition of agar (15 $\left.\mathrm{gl}^{-1}\right)$ (BD Difco, India) and bromo phenol blue at $0.0025 \mathrm{~g}$ as an indicator for monitoring the $\mathrm{pH}$ changes of the medium.

Enrichment and isolation of pure culture: Ten gram of soil samples was added to the mineral salt medium $(90 \mathrm{ml})$ and incubated at $30^{\circ} \mathrm{C}$ for $96 \mathrm{hr}$. The enriched broth $(10 \mathrm{ml})$ was subsequently transferred to fresh broth for isolating pure culture and incubated under same conditions. Sulphur oxidizing bacteria were isolated by directly plating $0.1 \mathrm{ml}$ of serially diluted enriched sample with $1 \mathrm{X}$ phosphate buffer saline and spread plated onto the sulphur-oxidizer agar plates and was incubated at $30^{\circ} \mathrm{C}$ for 96 $\mathrm{hr}$. After incubation, well defined isolated colonies were randomly picked and streaked onto sulphur-oxidizer medium plate to check for purity. For qualitative screening, the isolates were grown in the broth for a period of $168 \mathrm{hr}$. Broth $\mathrm{pH}$ was estimated at $24 \mathrm{hr}$ interval using $\mathrm{pH}$ meter (Eutech instruments, Mumbai, India). Bacterial isolates with ability to lower the $\mathrm{pH}$ of the broth were selected and preserved in glycerol at $-80^{\circ} \mathrm{C}$.

Sulphate ion production: The sulphate ion $\left(\mathrm{SO}_{4}{ }^{2-}\right)$ produced in the medium was measured according to the method of Cha et al. (1999) with spectrophotometer (Cary 100, UV-VIS spectrophotometer, Thermofisher Scientific, USA) by reacting 1:1 of the bacterial culture supernatant (prepared by centrifuging the bacterial broth culture at $1000 \mathrm{rpm}$ for $5 \mathrm{~min}$ ) with barium chloride solution $(10 \% \mathrm{w} / \mathrm{v})$. The suspension was shaken vigorously and measured with spectrophotometer at $450 \mathrm{~nm}$. The amount of sulphate formed was calculated from sulphate standard curve which was prepared by dissolving known concentrations ( 0 to 3 $\mathrm{mM}$ ) of potassium sulphate in deionized water following the method of Kolmert et al. (2000).

Sulphur oxidation assay: The sulphur-oxidase activity was measured spectrophotometrically (Cary 100, UV-VIS spectrophotometer, Thermofisher Scientific, USA) (450 nm) in the reaction mixture according to Hirano et al. (1996). The entire reaction was performed in a sealed vial $(10 \mathrm{ml})$ with the reaction 
initiation by adding $\mathrm{Na}_{2} \mathrm{~S}(0.5 \mathrm{ml})$ to the mixture containing sodium citrate buffer ( $4.5 \mathrm{ml} ; \mathrm{pH} 5.7$ and $0.1 \mathrm{M}$ ) and $1.0 \mathrm{ml}$ cell suspension and was incubated at $30^{\circ} \mathrm{C}$. The reaction was terminated with addition of $1 \mathrm{M} \mathrm{NaOH}(1.5 \mathrm{ml})$. The cells were removed from the resultant solution by centrifuging at $10,000 \mathrm{rpm}$ for $15 \mathrm{~min}$. The concentration of sulphate ion was determined by adding equal volume of barium chloride solution $(10 \% \mathrm{w} / \mathrm{v})$. The reactant and sulphide-oxidase activity were measured spectrophotometrically at $450 \mathrm{~nm}$. The enzyme oxidase activity (one unit) was defined as the amount required to produce $1 \mu \mathrm{mol}$ sulphate $\mathrm{hr}^{-1} \mathrm{ml}^{-1}\left(\mathrm{U} \mathrm{ml}^{-1}\right)$. For blank, sodium citrate buffer ( $\mathrm{pH}$ 6.0) was used to carry the reaction replacing the cell suspension.

Utilization of $\mathrm{Na}_{2} \mathrm{~S}$ in in-vitro conditions: All the six bacterial isolates utilizing $\mathrm{Na}_{2} \mathrm{~S}$ in in-vitro conditions were studied with twolayer agar method (Nelson et al., 1983). The chemolithoautotrophic growth was performed in fifty milliliter tubes with agar-based Starkeys mineral salt medium. The medium consisted of bottom $\operatorname{agar}(1.5 \% \mathrm{w} / \mathrm{v})$ with $\mathrm{Na}_{2} \mathrm{~S}$ (sulphide source), the middle layer was filled with culture and the top layer with semisolid agar $(0.7 \% \mathrm{w} / \mathrm{v})$ which was free off sulphide. To monitor the $\mathrm{pH}$ change (color), 1 $\mathrm{ml}$ of phenol red indicator $(0.1 \%)$ was added to the agar medium. Initially, the bottom layer was supplemented with $0.3 \mathrm{ml}$ of sterile 1 $\mathrm{M} \mathrm{Na}_{2} \mathrm{~S}$ (0.3 mM final concentration). The bottom agar was sterilized, cooled and added to $\mathrm{Na}_{2} \mathrm{~S}$ solution and allowed to solidify. Later, the grown sulphur oxidizing bacteria cultures were added (1 ml). Finally, the top sterilized semi solid agar was added and incubated at $30^{\circ} \mathrm{C}$ for $96 \mathrm{hr}$.

Identification of the bacterial isolates: Bacterial isolates in this study were identified as per standard methods (Brenner et al., 2005). The bacterial isolates were presumptively identified by means of morphological examination (shape, spore and motility), staining reaction (Gram's reaction) and biochemical tests (catalase production, oxidase production, methyl red reaction, indole production, nitrate reduction, nitrite reduction, carbohydrate metabolism (acid-gas production), thiosulphate utilization. The growth was recorded at $\mathrm{pH} 5$ and temperature $40^{\circ} \mathrm{C}$.

16s rRNA sequencing analysis: The isolates with sulphur oxidizing capability were taken for $16 \mathrm{~S}$ rRNA sequencing analysis. Bacterial cultures were pelleted and washed in $1 \mathrm{X} T E$ buffer (pH 8.0). Crude DNA was extracted by boiling lysis method. Amplification of $16 \mathrm{~S}$ rRNA region was performed using primers 27F 5'-GAGTTTGCTCCTGGCTCAG-3' and 1492R 5'GGTTACCTTGTTACGACTT-3'. The reaction was performed in a total of $25 \mu$ reaction mixture consisted of $12.5 \mu$ of $2 X$ OneTaq Quick load PCR master mix (New England Biolabs, Germany), $0.5 \mu \mathrm{l}(20 \mathrm{pmol})$ of each of the primers and $2 \mu \mathrm{l}$ of DNA template and $9.5 \mu$ distilled water. The PCR cycling conditions i.e., $94^{\circ} \mathrm{C}(2$ $\mathrm{min}$ ) for initial denaturation were maintained followed by 35 cycles of denaturation, annealing and extension at $94^{\circ} \mathrm{C}(30 \mathrm{sec}), 50^{\circ} \mathrm{C}$ $(1 \mathrm{~min})$ and $68^{\circ} \mathrm{C}(90 \mathrm{sec})$ with a final extension at $68^{\circ} \mathrm{C}(7 \mathrm{~min})$. The amplicons were analyzed by agarose gel electrophoresis and visualized in gel documentation system (Biorad, Germany). GenElute Gel extraction kit (Sigma, USA) was used for purification of amplicons and outsourced for sequencing at Scigenome Pvt. Ltd. (Cochin, India). Chromatogram analysis was performed in Mega Version 4 and checked for sequencing similarity for calculation of average nucleotide identity (ANI) values by using EzBioCloud (http://www.ezbiocloud.net/). Phylogenetic analysis with related species and genus was performed in Clustal omega. Genetic relatedness among the sulphur oxidizing bacteria isolates were analysed using Clustal 2.1.

Statistical analysis: One-way ANOVA was used for data analysis SPSS V. 16 software (SPSS Inc., Chicago, Ilinois, USA). The means were compared using Duncan multiple range test to find the difference at $5 \%$ level of significance $(P<0.05)$.

\section{Results and Discussion}

Aquaculture farm soil samples were screened for sulphur oxidizing bacteria using enrichment culture technique in mineral salt medium. The enriched soil samples were able to produce colonies up to $10^{-5} \mathrm{ml}$ dilutions on agar medium. A total of fifty distinct bacterial isolates were picked and checked for their purity by subsequent sub culturing and were maintained on slants. Out of fifty isolates, six isolates showed characteristic reduction of $\mathrm{pH}$ from 7 to 3 within $96 \mathrm{hr}$ of incubation and were selected for further studies. Sulphur oxidizing bacteria can use sulphur as a fundamental substrate during oxidation process and oxidizes it to sulphates (Pokorna and Zabranska, 2015).

The genus Thiobacillus among sulphur oxidizing bacteria plays a very important role in the biological oxidation of sulphur in natural environment (Yang et al., 2010). In previous study, sulphur oxidizing bacteria has been isolated from the freshwater fish farm soil (Kumar et al., 2018). Sulphur oxidizing bacteria has also been isolated from pulses rhizosphere, biogas slurry, paddy rhizosphere, mine soil, sewage and tannery effluent (Vidyalakshmi and Sridar, 2006). Another study conducted by Behera et al. (2014) from mangrove soil of Mahanadi river have also reported screening of sulphur oxidizing bacteria. Thiobacilli generally enhances sulphur oxidation rate and reduces the level of toxic gases such as $\mathrm{H}_{2} \mathrm{~S}$ in aquaculture environment. Substantial quantum of phosphorous, nitrogen and organic matter are usually received and accumulated in aquaculture ponds during intensive farming (Vass, 2017).

This high load of organic matter contributes in the development of anaerobic conditions in soil water interface resulting in production of reduced toxic gases such as hydrogen sulphide, nitrite and ammonia (Muralidhar, 2017). These reduced compounds are toxic to aquatic animals and are majorly documented in intensively stocked and fed shrimp farms (Patil et al., 2012, 2015; Abraham et al., 2004, 2015). Thiobacillus spp. can oxidize sulphur at $\mathrm{pH}$ ranging from 1 to 9 , but optimum growth is recorded only under acidic conditions of $\mathrm{pH} 1$ to 5 (Robertson and Kuenen, 2006). Decrease in $\mathrm{pH}$ to 2.5-3.0 from neutral during growth of sulphur oxidizing bacteria varies within species. In 

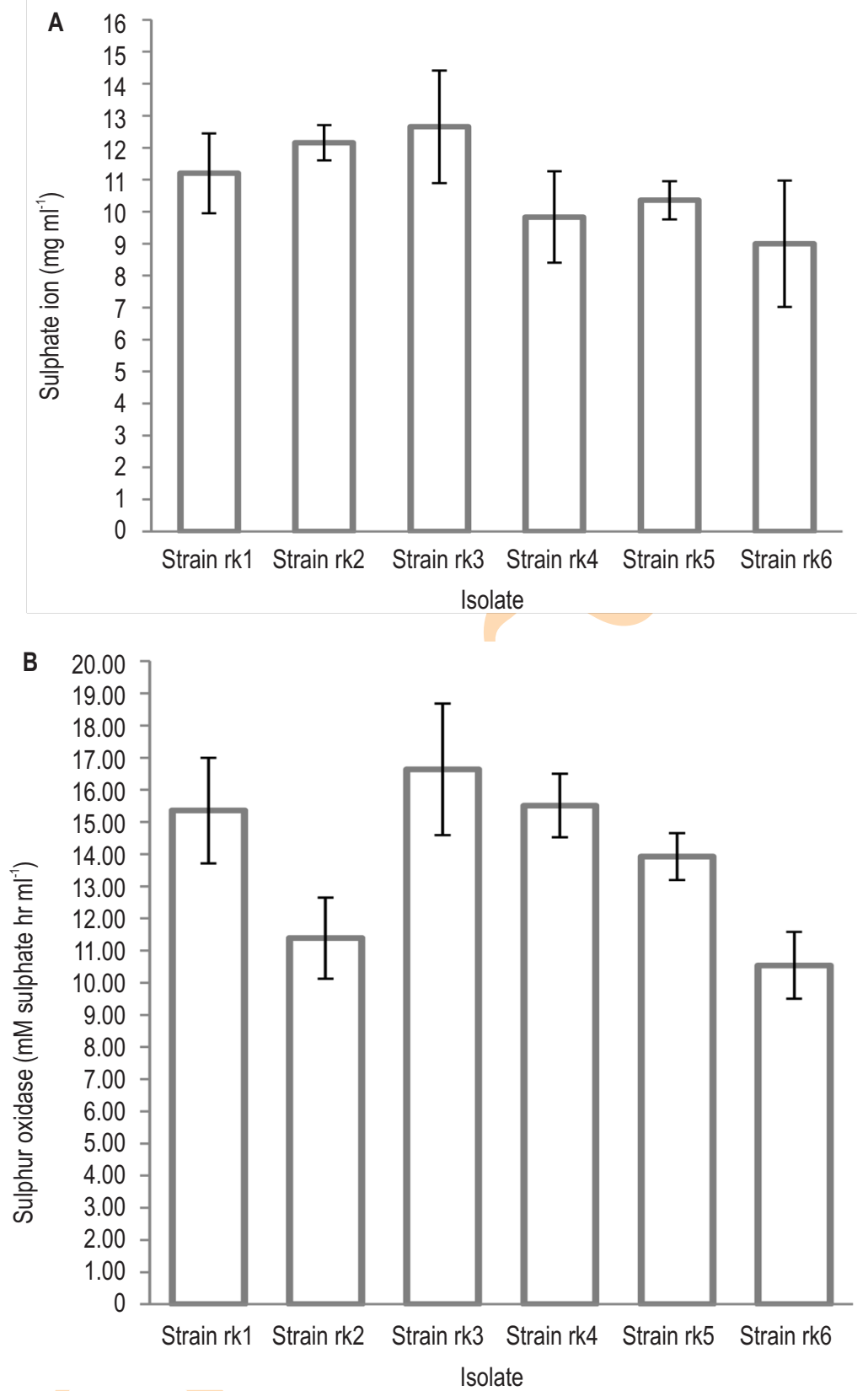

Fig. 1: Sulphate ion produced by the six sulphur oxidizing bacterial isolates in the medium. Maximum amount of sulphate ion (12.65 mg ml-1) was produced by bacterial isolate Halothiobacillus sp. strain rk3. B) Sulphur oxidation activity of six sulphur oxidizing bacterial isolates. Maximum activity of

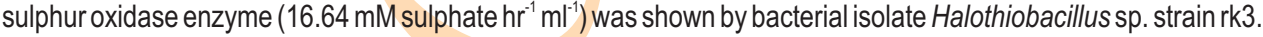

majority, optimum growth was noticed at $\mathrm{pH} 6.5$ to 8.0 and temperature 30 to $42^{\circ} \mathrm{C}$ (Kelly and Wood, 2003). However, in our study all the six isolates were found to grow at $40^{\circ} \mathrm{C}$. During growth of sulphur oxidizing bacteria, the amount of sulphate ion $\left(\mathrm{SO}_{4}^{2}\right)$ produced is shown in Fig. 1A. Maximum sulphate ion $\left(12.65 \mathrm{mg} \mathrm{ml}^{-1}\right)$ was produced by bacterial isolate Halothiobacillus sp. strain rk3. There was no significant difference $(P>0.05)$ noticed for sulphate ion produced among the six isolates. Barium chloride test was used to measure the amount of sulphate ion produced during the oxidation of sulphur into sulphate by sulphur oxidising bacteria. In a recent study, sulphate production from thiosulphate by sulphur oxidizing bacteria (isolated from freshwater fish farm soil) was found to be 1.42 to1.62 $\mathrm{mg} \mathrm{ml}^{-1}$ (Kumar et al., 2018). Sulphate production by the isolates BGS2 and TRY2 was found to be 79.20 and $68.80 \mathrm{mg}$ per $100 \mathrm{ml}$ broth (Vidhyasri and Sridar, 2011). In another study, sulphate production 


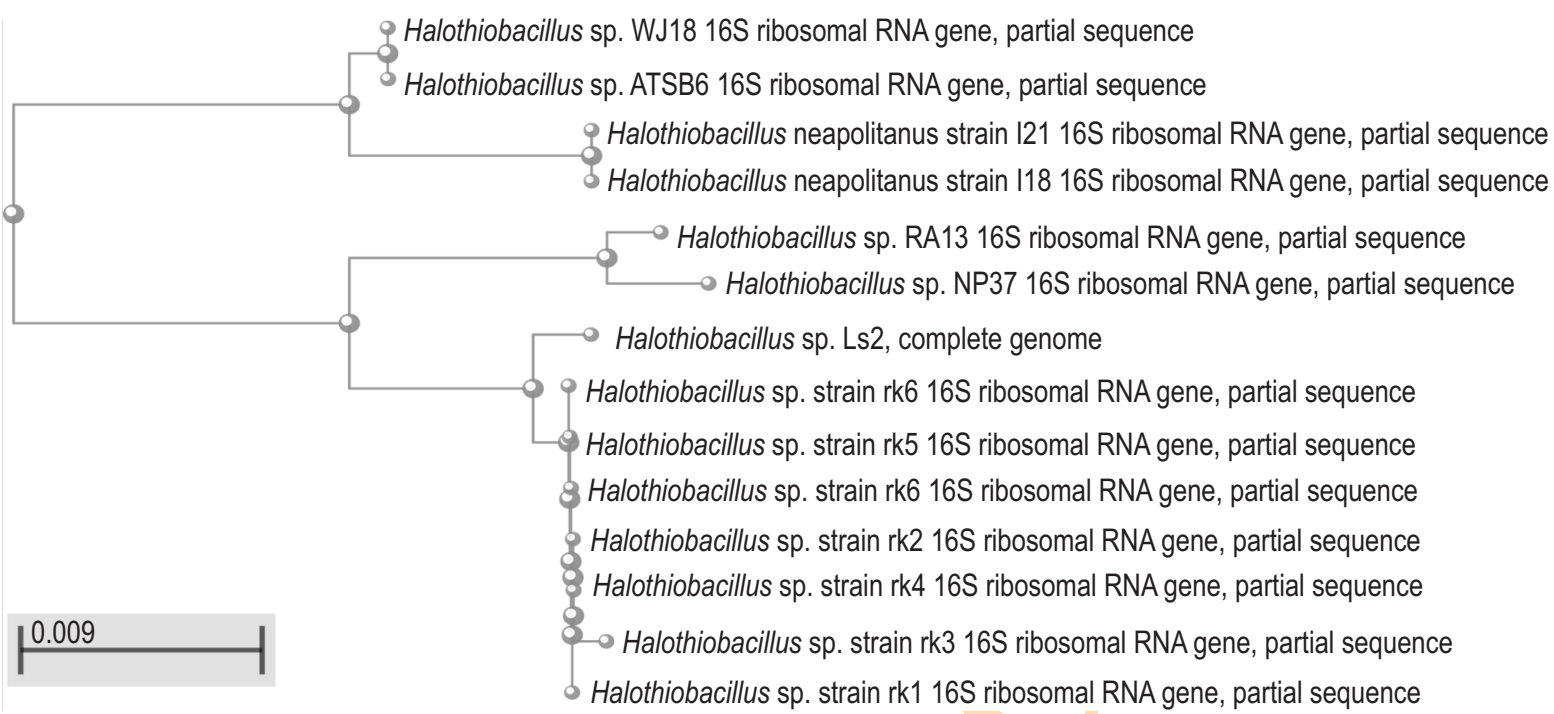

Fig. 2 : Phylogenetic tree of bacterial isolates constructed using 16S rRNA gene partial sequences by neighborhood joining method. The reference sequences of Halothiobacillus sp. and Halothiobacillus neopalinatus is selected from the public domain (NCBI) and compared with the six sulphur oxidizing bacterial isolates which forms a distinct clade. The bar represents a sequence divergence of $0.009 \%$.

by ten bacterial strains isolated from industrial wastewater, sewerage water and sulphur mud varied from 13.4 to $571.6 \mathrm{mgl}^{-1}$ after 8 days of incubation (Ullah et al., 2014).

The sulphur-oxidase activity of six bacterial isolates is shown in Fig. 1B. The maximum activity of sulphur oxidase enzyme (16.64 mM sulphate $\mathrm{hr}^{-1} \mathrm{ml}^{-1}$ ) was shown by bacterial isolate Halothiobacillus sp. strain rk3. There was no significant difference $(P>0.05)$ noticed for sulphide oxidation among the bacterial isolates. Sulphur oxidizing bacteria can oxidize sulphide and inorganic sulphur reduced compounds due to the production of sulphur oxidase enzyme (Ravichandra et al., 2007), sulphate is formed from biological oxidation of the reduced inorganic sulphur compounds (Thatoi, et al., 2012).

All the six sulphur oxidizing bacteria isolates were screened for the utilization of $\mathrm{Na}_{2} \mathrm{~S}$ in in-vitro conditions. There was change in color of the medium to yellow which indicates a decrease in $\mathrm{pH}$. Oxidation of $\mathrm{Na}_{2} \mathrm{~S}$ was evidenced by the presence of white mat like structure between the two agar layers indicating that $\mathrm{Na}_{2} \mathrm{~S}$ is oxidized by sulphur oxidizing bacteria and forms precipitate which is deposited in the tube. Utilization of $\mathrm{Na}_{2} \mathrm{~S}$ has also been studied for MKH41 isolate in in-vitro condition (Mustafa et al., 2015). The change in pH observed in the present

Table 1: Morphological, physiological and biochemical characterization identification of sulphur oxidizing bacteria

\begin{tabular}{|c|c|c|c|c|c|c|}
\hline Characters & Strain rk1 & Strain rk2 & Strain rk3 & Strain rk4 & Strain rk5 & Strain rk6 \\
\hline Shape & Thin rod & Thin rod & Thin rod & Thin rod & Thin rod & Thin rod \\
\hline Spore & - & - & - & - & - & - \\
\hline Motile & + & + & + & + & + & + \\
\hline Aerobic growth & + & + & + & + & + & + \\
\hline Gram stain & - & - & - & - & - & - \\
\hline Catalase test & - & - & - & - & - & - \\
\hline Oxidase test & - & - & - & - & - & - \\
\hline MR test & - & - & - & - & - & - \\
\hline Indole production & + & + & + & + & + & + \\
\hline Fermentation of glucose & + & + & + & + & + & + \\
\hline Nitrate reduction & + & + & + & + & + & + \\
\hline Nitrate reduction & - & - & - & - & - & - \\
\hline Thiosulphate utilization & + & + & + & + & + & + \\
\hline Growth at pH 5 & + & + & + & + & + & + \\
\hline Growth at $40^{\circ} \mathrm{C}$ & + & + & + & + & + & + \\
\hline
\end{tabular}


Table 2: Genetic relatedness among the sulphur oxidizing bacterial isolates

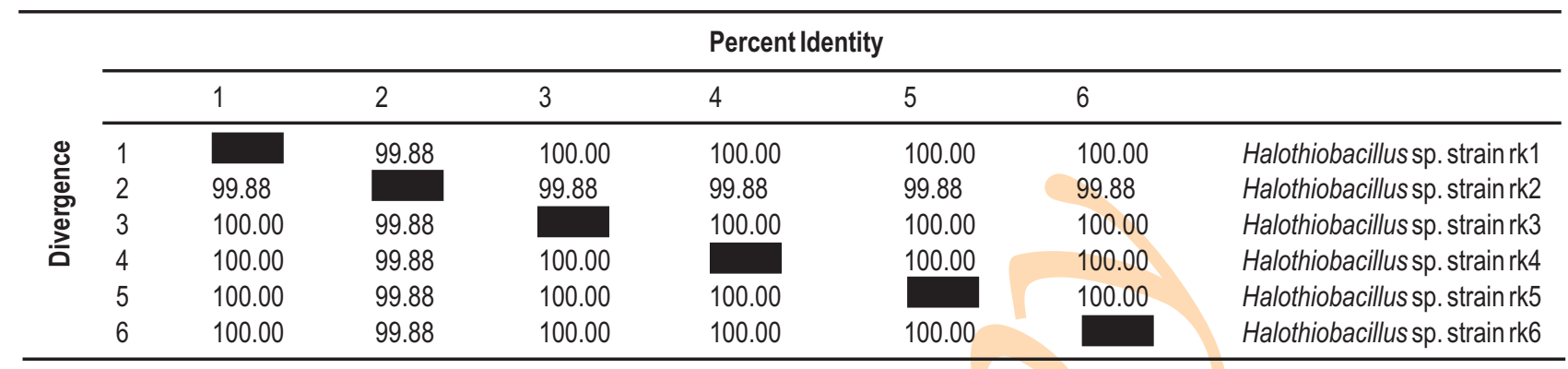

study might be due to the utilization of $\mathrm{Na}_{2} \mathrm{~S}$ and formation of sulphuric acid (Friedrich et al., 2001). Identification of these isolates was performed as per standard procedures using morphological, physiological and biochemical characters (Table 1). On mineral salt agar plates isolates produced small colonies ( $1 \pm 3 \mathrm{~mm}$ diameter) with white to yellowish centre. The isolates were Gram-negative, non-spore producing thin rod shaped single occurring (occasionally in pair) motile bacteria. All six isolates were obligate aerobes and showed chemolithoautotrophic growth with thiosulphate. Study on physiological and biochemical characteristics of these six isolates revealed that they were negative for catalase, oxidase, methyl red, produced indole/acid and reduced nitrate, but not nitrite.

The bacteria also showed heterotrophic growth at $\mathrm{pH} 5$ and temperature $40^{\circ} \mathrm{C}$. For molecular characterization, amplicons of $1500 \mathrm{bp}$ size were purified and sent for sequencing. 16S rRNA sequencing analysis revealed that the sulphur oxidizing bacteria isolated in the present study belonged to the genus Halothiobacillus of c-Proteobacteria which are frequently isolated from the soil, freshwater, and marine environments (Kelly and Wood, 2003). Further, clustering and dendrogram revealed that the isolates were closely related. Phylogenetic tree of $16 \mathrm{~S}$ rRNA gene was constructed with six isolates obtained in this study in comparison to the reference Halothiobacillus sp. and Halothiobacillus neopalinatus available in the public domain NCBI (Fig. 2). The study revealed that the reference strains (LS2) formed a monophyletic cluster with $99 \%$ identity with these bacterial isolates. The genetic relatedness among the sulphur oxidizing bacteria is depicted in Table 2 . The percent identity observed among the isolates was nearly $100 \%$, suggesting that there was not much variation in the $16 \mathrm{~S}$ rRNA sequences.

The nucleotide sequence data are available in public domain under the Genbank accession numbers [MG014236.1: Halothiobacillus sp. strain rk1 (ANI-99.42\%); MG014237.1: Halothiobacillus sp. strain rk2 (ANI-99.65\%); MG014238.1: Halothiobacillus sp. strain rk3 (ANI-99.51\%); MG014239.1: Halothiobacillus sp. strain rk4 (ANI-99.39\%); MG014240.1: Halothiobacillus sp. strain rk5 (ANI-99.54\%) and MG014241.1: Halothiobacillus sp. strain rk6 (ANI-99.54\%)]. Similarity in ANI values indicates that the genomes of all six sulphur oxidizing bacterial strains are almost identical in size and no significant variance were observed in the ANI values. In conclusion, the present investigation revealed that sulphur oxidizing bacteria can oxidize sulphur and utilize $\mathrm{Na}_{2} \mathrm{~S}$ in in-vitro conditions. Therefore, these bacteria may be used as bio-inoculants in the shrimp culture environment to enhance sulphur oxidation in soil. However, further studies need to be carried out along with in situ trials with shrimps to develop proper understanding on the roles played by these bacteria in sulphur oxidation process.

\section{Acknowledgments}

Authors are grateful to the Indian Council of Agricultural Research, New Delhi, India, for the financial support and to the Director, ICAR-Central Institute of Fisheries Technology, Cochin, India, for providing all the facilities required for the present study.

\section{References}

Abraham, T.J.S., S. Ghosh, T.S. Nagesh and D. Sasmal: Assessment of nitrogen and sulphur cycle bacteria and shrimp production in ponds treated with biological products. J. Coastal Life Med., 3, 466-470 (2015).

Abraham, T.J.S., S. Ghosh and D. Sasmal: Distribution of bacteria involved in nitrogen and sulphur cycles in shrimp culture systems of West Bengal, India. Aquaculture, 239, 275-288 (2004).

Behera, B.C., M. Patra, S.K. Dutta and H.N. Thatoi: Isolation and characterization of sulphur oxidizing bacteria from mangrove soil of Mahanadi river delta and their sulphur oxidizing ability. J. Appl. Environ. Microbiol., 2, 1-5 (2014).

Behera, B.C., R.R., Mishra, S.K. Dutta and H.N. Thatoi: Sulphur oxidising bacteria in mangrove ecosystem: A review. African J. Biotechnol., 13, 2897-2907 (2014).

Boyd, C.E.: Shrimp pond bottom soil and sediment management Proceedings of the special session on shrimp farming (Ed.: J. Wyban). World Aquatic Society, Baton Rouge, LA, pp. 166-180 (1992).

Brenner, D.J., N.R. Krieg and J.T. Staley: Bergey's Manual of Systemic Bacteriology. The Proteobacteria, Part B: The Gammaproteobacteria (Eds.: G. Garrity, D.J. Brenner, N.R. Krieg and J.R. Staley), Vol. 2, p. 1106 (2005).

Cha, J.M., W. S. Cha and J.H. Lee: Removal of organo-sulphur odour compounds by Thiobacillus novellus SRM, sulphur-oxidizing bacteria. Process Biochem., 34, 659-665 (1999).

Colby, P.J. and L.L. Smith: Survival of walleye eggs and fry on paper fiber sludge deposits on rainy river, Minnesota. Transac. American 
Fisheries Soc., 96, 278-296 (1967).

Devaraja, T.N., F.M. Yusoff and M.Y. Shariff: Changes in bacterial populations and shrimp production in ponds treated with commercial microbial products. Aquaculture, 206, 245-256 (2002).

Friedrich, C.G., D. Rother, F. Bardischewsky, A. Quentmeier and J. Fischer: Oxidation of reduced onorganic sulfur compounds by bacteria: Emergence of a common mechanism? Appl. Environ. Microbiol., 67, 2873-2882 (2001).

Hirano, T., H. Kurosawa, K. Nakamura and Y. Amano: Simultaneous removal of hydrogen sulfide and trimethylamine by a bacterial deodorant. J. Ferment. Bioeng., 81, 337-342 (1996).

Jorgensen, B.B. and N.P. Revsbech: Colorless sulfur bacteria, Beggiatoa spp. and Thiovulum spp., in $\mathrm{O}_{2}$ and $\mathrm{H}_{2} \mathrm{~S}$ microgradients. Appl. Environ. Microbiol., 45, 1261-1270 (1983).

Kawahara, N., K. Shigematsu, S. Miura, T. Miyada and R. Kondo: Distribution of sulfate-reducing bacteria in fish farm sediments on the coast of southern Fukui Prefecture, Japan. Plankton Benthos Res., 3, 42-45 (2008).

Kelly, D.P. and A.P. Wood: Genus III Halothiobacillacae In: Bergey's Manual of Systematic Bacteriology. $2^{\text {nd }}$ Edn., Vol. 2 Part B. Springer, New York, pp. 58-59 (2003).

Kelly, D.P. and A.P. Harrison: Genus Thiobacillus Beijerinck. In: Bergey's Manual of Systematic Bacteriology (Eds.: J. T. Staley, M.P. Bryant, N. P fennig and J. G. Holt ). $1^{\text {st }}$ Edn., Vol. 3, Williams \& Wilkins, pp. 1842-1858 (1989).

Kolmert, Å.P., P. Wikström and K.B. Hallberg: A fast and simple turbidimetric method for the determination of sulfate in sulfatereducing bacterial cultures. J. Microbiol. Meth., 41, 179-184 (2000).

Kuenen, J.G., L.A. Robertson and O.H. Tuovinen: The genera Thiobacillus, Thiomicrospira, and Thiosphaera. In: The Prokaryotes (Eds.: A Balows, H.G. Truper, M. Dworkin, W. Harder and K.H. Schleifer). $2^{\text {nd }}$ Edn., New York: Springer, pp. 2638-2657 (1992).

Kumar, P.R., S. Pothana, G. Manivannan and S. Manikandan: Microbiological and molecular characterization of sulphur oxidizing Pseudomonas sp. PRK786 isolated from cattle manure compost. Int. J. Adv. Res., 2, 714-722 (2014).

Kumar, N.R., K.K. Archana, K.A. Basha, T. Muthulakshmi, T.C. Joseph and M.M. Prasad: Isolation and identification of sulphur oxidizing bacteria from freshwater fish farm soil. Fish. Technol., 55, 270-275 (2018).

Muralidhar, M., R. Saraswathy, J.S. Dayal and K.K. Vass: Nitrogen assessment and management in brackish-water aquaculture of India. In: The Indian Nitrogen Assessment. Sources of reactive nitrogen, environmental and climate effects, management options, and policies (Eds.: Y.P. Abrol, K.T. Adhya, V.P. Aneja, N. Raghuram, H. Pathak, U. Kulshrestha, C. Sharma and B. Singh) pp. 287-303 (2017).

Mustafa, I., H. Ohta, T. Niidome and S. Morimura: Isolation of heterotrophic thiosulfate-oxidising bacteria and their role in a conserved tidal flat in the Ariake Sea, Japan. J. Ecol. Nat. Environ., 7,106-112 (2015).

Nelson, D.C. and H.W. Jannasch: Chemoautotrophic growth of a marine Beggiatoa in sulfide-gradient cultures. Arch. Microbiol., 136, 262269 (1983)

Patil, P.K., M. Muralidhar, H.G. Solanki, K. Patel, C. Gopal and S.M. Pillai: Trends in beneficial and pathogenic bacterial populations and their relation with environmental parameters in tiger shrimp, Penaeus monodon culture ponds. Int. J. Bio-Res. Stress Manag., 4, 107-113 (2012).

Patil, P.K., M. Muralidhar, H.G. Solanki, K. Patel, P.P. Patel and C. Gopal: Effect of culture intensity and probiotics application on microbiological and environmental parameters in Litopenaeus vannamei culture ponds. J. Environ. Biol., 37, 21-29 (2015).

Pokorna, D. and J. Zabranska: Sulfur-oxidizing bacteria in environmental technology. Biotech. Adv., 03, 1246-1259 (2015).

Rangasamy, A., R. Sridar, P. Nalayini, M. Madhaiyan, G.P. Indira, K.H. Choi and T.M. Sa: Isolation of sulfur oxidizing bacteria from different ecological niches. Kor. J. Soil Sci. Fert., 38, 180-187 (2005).

Rao, P.S.S. and I. Karunasagar: Incidence of bacteria involved in nitrogen and sulphur cycles in tropical shrimp culture ponds. Aquacult. Int., 8, 463-472 (2000).

Ravichandra, P., G. Mugeraya, A. Ganganirao, M. Ramakrishna and A. Jetty: Isolation of Thiobacillus sp., from aerobic sludge of distillery and dairy effluent treatment plants and its sulfide oxidation activity at different concentrations. J. Environ. Biol., 28, 819-823 (2007).

Robertson, L.A. and J.G. Kuenen: The colorless sulfur bacteria. Prokaryotes, 2, 985-1011 (2006).

Robertson, L.A. and J.G. Kuenen: The genus Thiobacillus. Prokaryotes, 5, 812-27 (2006).

Rojas, A., G. Holguin, B.R. Glick and Y. Bashan: Synergism between Phyllobacterium sp. (N2-Fixer) and Bacillus licheniformis (PSolubilizer), both from a semiarid mangrove rhizosphere. FEMS Microbiol. Ecol., 35, 181-187 (2001).

Sridar, R., K. Veerender, M. Sivaji and R. Gayathri: Genetic diversity of sulphur oxidizing bacteria from different ecosystems. Indian J. Biotechnol., 14, 72-80 (2015).

Starkey, R.L.: Isolation of some bacteria which oxidize thiosulfate. Soil Sci., 39, 197-219 (1935).

Thatoi, H.N., B.C. Behera, T.K. Dangar and R.R. Mishra: Microbial biodiversity in mangrove soil of Bhitarakanika, Odisha, India. Int. J. Environ. Biol., 2, 50-58 (2012).

Ullah, I., G. Jilani, K.S. Khan, M.S. Akhtar and M. Rasheed: Sulphur oxidizing bacteria from sulphur rich ecologies exhibit high capability of phosphorous solubilization. Int. J. Agricult. Biol., 16, 550-556 (2014).

Vass K.K., G.N. Chattopadhyay, S. Adhikari, S. Datta and S. Samanta: Assessment of nitrogen in freshwater aquaculture in India. In: The Indian Nitrogen Assessment. Sources of reactive nitrogen, environmental and climate effects, management options, and policies (Eds.: Y.P. Abrol, K.T. Adhya, V.P. Aneja, N. Raghuram, H. Pathak, U. Kulshrestha, C. Sharma and B. Singh) pp. 267-286 (2017).

Veerender, K., R. Sridar and M. Sivaji: Isolation and characterization of sulphur oxidizing bacteria from different ecosystems. Prog. Res., 9, 104-107 (2014).

Vidhyasri, S. and R. Sridar: Development of a carrier based formulation of sulphur oxidizing bacterium for enhancing the productivity of crops requiring sulphur nutrition. J. Basic Appl. Sci. Res., 1, 345353 (2011).

Vidyalakshmi, R. and R. Sridar: Isolation and characterization of sulphur oxidizing bacteria. J. Cult. Col., 5, 73-77 (2006).

Yang, Z.H., K. Stoven, S. Haneklaus, B.R. Singh and E. Schnug: Elemental sulfur oxidation by Thiobacillus spp. and aerobic heterotrophic sulfuroxidizing bacteria. Pedosphere, 20, 71-79 (2010). 